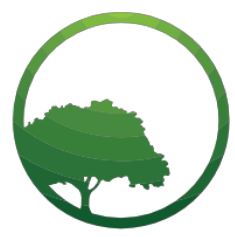

Business \& Social Science IJRBS

\section{Research in Business and Social Science}

IJRBS Vol 8 No 2, ISSN: 2147-4478

Contents available at www.ssbfnet.com/ojs

\title{
Design of Excellent Service Model on Department of Population and Civil Registration In City of Metro, Indonesia
}

\author{
M Yusuf S Barusman
}

Corresponding Author: Faculty of Economic and Business, University of Bandar Lampung Jl. Zainal Abidin Pagar Alam No.26, Labuhan Ratu, Kedaton, 35142, Bandar Lampung, Indonesia

\section{Margono}

Faculty of Economic and Business, University of Bandar Lampung Jl. Zainal Abidin Pagar Alam No.26, Labuhan Ratu, Kedaton, 35142, Bandar Lampung, Indonesia

\section{Appin Purisky Redaputri}

Faculty of Economic and Business, University of Bandar Lampung Jl. Zainal Abidin Pagar Alam No.26, Labuhan Ratu, Kedaton, 35142, Bandar Lampung, Indonesia

\begin{abstract}
The purpose of this study is "Designing an excellent service model on Population and Civil Registration Service in the city of Metro ". The conclusions obtained from this study are (1) Problems in excellent service at Population and Civil Registration Service in the city of Metro based on their nature are divided into two types, which is uncontrolled (missed) and which is controlled (difficult). Uncontrolled problems are problems that should not need to exist, but they appear as an unavoidable problem whereas problems that are controlled are problems whose level of difficulty can be controlled. (2). The focus of service in population administration services in an institutional model emphasizes speed and convenience and does not pay attention to the simplicity of requirements and so to improve its quality it is necessary to pay attention to safety factors. (3) There are still many brokers in the services of the city of Metro Population and Civil Registration Service due to lack of supervision from the relevant agencies, not yet clear the application of Procedure Service Standards as well as the lack of socialization to the public about the service rates and service procedures.
\end{abstract}

Key words: Excellent Service Model; Soft Systems Methodology

JEL classification: 014

Submitted: 14.02.2019 - Accepted: 11.03.2019 


\section{Introduction}

The community connotes that the services provided by government officials to the people tend to be less and not of high quality. Whereas according to Gouthier et al (2014) providing better core services or value-added services has emerged as determinants of success. This can be seen by the number of complaints submitted to unscrupulous government officials who provide services to the public. One complaint that is often heard from the public relating to government apparatus is that it is not only complicated due to the long and rigid bureaucracy and the behavior of individual officers who are sometimes less friendly. This reality requires concern from the apparatus, so that people get excellent service. Crime in service delivery will in turn get recognition for the quality of services that satisfy the community.

Excellent service is concern for customers. Excellent service is basically a sense of concern for profit-oriented organizations or social-oriented organizations (non-profit) towards customers that are indicated by attitudes, attention, and concrete actions, so that customers feel comfortable with the excellent service provided (Pratomo et al , 2000). Excellent Service or Service Excellent is is supposed to generate extraordinary satisfaction, or what Rust et al (2000) describe as positive customer emotions resulting from the unexpected transgression of their expectations. Excellent service is a service that provides customer satisfaction. This is in accordance with the Decree of the Minister of State for Administrative Reform (MenPAN) Number 81/1993. In this decision the joints of excellent services include simplicity, clarity and certainty, security, openness, efficiency, economics, equitable justice, and timeliness.

The Population and Civil Registration Service of the city of Metro is a Regional Device Organization in the city of Metro that implements population administration services so that it is required to be able to carry out excellent service to the community. The office has the main task of carrying out part of the regional government affairs based on the principle of regional autonomy and the task of rising in the field of population and Civil Registration. In carrying out these basic tasks, the office has the following functions:

i. Formulating technical policies in the field of population administration services, Civil Registry, Population Information Technology, Monitoring Population Evaluation and Reporting, and Civil Registration.

ii. Organizing government affairs and public services in the field of population administration services, Civil Registration, Population Information Technology, Monitoring Population Evaluation and Reporting and Civil Registration.

iii. Guiding and implementing tasks in the field of population administration services, Civil Registration, Population Information Technology, Monitoring Population Evaluation and Reporting and Civil Registration.

iv. Implementing other duties given by the Mayor in accordance with their main duties and functions.

In various Regional Governments which restructured their services there were indications that showed a positive correlation between the improvement of public services and the satisfaction of the community receiving services from the Government itself. The Data on the Realization of the Population Administration and Civil Registration Services of the city of Metro are listed below: 
Barusman et al. / International Journal of Research in Business and Social Science, Vol 8 No 2, 2019 ISSN: 2147-4486

Table 1: List of Realization of Population Administration Services at City of Metro Population and Civil Registration Service

\begin{tabular}{|l|l|l|l|l|}
\hline NO & KIND OF SERVICE & TARGET & REALIZATION & PERCENTAGE \\
\hline 1 & Electronic Identity Card Service & 121.274 & 111.013 & $91,53 \%$ \\
\hline 2 & Family Card Service & 48.220 & 40.990 & $85,01 \%$ \\
\hline 3 & Birth Certificate Services & 1.734 & 1.161 & $66,95 \%$ \\
\hline 4 & Death Deed Service & 446 & 320 & $71,75 \%$ \\
\hline 5 & Child Identity Card Service & 50.304 & 45.099 & $89,65 \%$ \\
\hline 6 & Administrative Services for Moving Letters & 110 & 90 & $81,81 \%$ \\
\hline Average & \multicolumn{4}{l}{} \\
\hline
\end{tabular}

The city of Metro Population and Civil Registration Office as one of the Regional Devices Organizations in Metro City that provides population administration services to the public is also not immune from various problems related to the implementation of public services. Some of the problems that often occur include the demands of the community for service improvements in terms of population administration completeness as a condition in managing population administration physically, easily, and quickly. Then according to observations we often encountered long lines when doing population administration services. In addition, the issue of work time service coincides with community work time. Often people have to leave their activities or ask for permission not to enter so they can take care of population administration such as making electronic ID cards or family cards or birth certificates. If the service provided is not on time, the community must spend more time managing the Electronic ID cards or the Family Card. This shows that the maximum implementation of operational standard service procedures such as timeliness, service processes, facilities, suitability of costs, officer responsiveness, and justice in carrying out public services. This is a problem for the city of Metro Population and Civil Registration Service to improve public services.

Service quality (SQ), in its contemporary conceptualisation, is a comparison of perceived expectations of a service with perceived performance (Lewis et al, 1983). This conceptualistion of service quality has its origins in the expectancy-disconfirmation paradigm (Oliver et al, 1994). So perceived service quality is an important predictor of customer satisfaction (Mwangi et al, 2018). And services quality had a positive and significant effect of the customers' loyalty (Sadhiarta et al, 2019). To be able to improve service quality and solve problems that often occur in public organizations, an innovation is needed so that services can be better. Innovation is about creating competitive advantage and Innovation is the only way of solution to achieve sustainable growth, social welfare and employment in a country (Vardalier et al, 2015). According to Sutton (2013), the 'human' aspect of service offerings is often ignored or underestimated by service managers. While managerial innovation as an internal change agent plays a central role in coping with the speed of today's fast-paced customer demand and highly competitive market (Gashema et al, 2018). With this organizational culture it is increasingly difficult to build competitive advantage. Employees contacted, often a source of differentiation that creates competitive advantage. The use of technological innovations in the implementation of public services in various public organizations including the Metro City Population and Civil Registration Office is increasingly explored to create customer / community satisfaction. The development of society and the economy are increasingly driven by technological innovation, there are new demands for efficiency, productivity, people's access to information in the government bureaucracy and demands for certainty and safe and comfortable. Based on the background described, it is necessary to make an Excellent Service Model for the appropriate the city of Metro Population and Civil Registration Service. 


\section{Reserch and Methodology}

This research was conducted at the city of Metro Population and Civil Registration Service located on Imam Bonjol street number 20, Hadimulyo Barat Sub-District Metro District, Metro City Center. This research is an exploratory study with a system approach, namely research that uses literature studies, interview guidelines, and observation as a data collection tool. Then the data is collected and processed qualitatively.

The data in this study are in the form of knowledge obtained from selected experts, through in-depth interviews. Participants in an in-depth interview are encouraged and promoted to talk in depth about the topic under study. As in-depth interview is considered a qualitative method of data collection, it is also called qualitative interviewing (Showkat et al, 2017). Knowledge is information that is analyzed and organized so that it can be understood and used in problem solving and decision makers. In this study, we set experts based on the sampling method or "purposive sampling" because we must dig up the right information and can be accounted for. What the experts have chosen is having the authority, experience, knowledge and insight according to their fields.

The resource persons in this study were experts consisting of the city of Metro Population and Civil Registration Office officials, Sub-district head, Village Chief, and Chairperson of hamlet (RW)/neighborhoods (RT) with the criteria of having authority and competencies related to the process of population administration services in the city of Metro. All speakers in this study had the opportunity to be interviewed.

Data collection in this study is to process data from primary and secondary data obtained from literature studies and field studies. Primary data is data collected and obtained directly from an organization or individual directly from the object or place of research in this study. Secondary data is data obtained in the form of information that has been collected and processed by other parties.

In the data collection technique in this study, we use the technique:

1. Literature Study (library research). In this technique data collection is done by studying various literature books, documents and reports relating to research problems in order to obtain secondary data which will be used as a theoretical basis in seeing and discussing the facts encountered in research in the field.

2. Observation. According to Sugiyono( Sugiyono, 2005), observation is data collection by making direct observations on the problem of the object of research, participating, where we come to the location and participating in the implementation of activities.

3. Interview. The interview technique is to obtain data by holding oral questions and answers with predetermined sources. Our interview technique consisted of two types, namely Depth Interview and free interview. According to Sugiyono( Sugiyono, 2005), in-depth interviews were question and answer conducted between interviewers and informants holding interview guides as instruments. Free interview, according to Sugiyono( Sugiyono, 2005), is an interview process where the interviewer accidentally directs question and answer to other issues related to the focus of research to obtain additional information.

To process the data in this study, we use Soft System Methodology(Barusman and Sulfarano, 2018) as an approach to design a system of stakeholder relations that can be seen in population administration service procedures. Then we made a comparison between the institutional model and the root definition model designed through the CATWOE technique. The results of the comparison of the two models were then analyzed qualitatively to be used as the most appropriate system design in the population administration service procedure model. 
Barusman et al. / International Journal of Research in Business and Social Science,

Vol 8 No 2, 2019 ISSN: 2147-4486

Table 2: Operational Definition of Variables

\begin{tabular}{|l|l|l|}
\hline Variable & Dimension & Operational Definition \\
\hline \multirow{5}{*}{$\begin{array}{l}\text { Soft System } \\
\text { Method }\end{array}$} & $\begin{array}{l}\text { Problem Mapping } \\
\text { accordance with real problems (root } \\
\text { definitions) }\end{array}$ & $\begin{array}{l}\text { Understanding problematic problem, structuring the problem } \\
\text { using the process description to understand the core of the } \\
\text { problem. }\end{array}$ \\
\cline { 2 - 3 } & $\begin{array}{l}\text { Development of a conceptual model } \\
\text { based on root definition }\end{array}$ & $\begin{array}{l}\text { Identify the parties involved, the patterns of interaction, the } \\
\text { way they look and the environment around them in order to } \\
\text { build the right system of activities to solve problems. }\end{array}$ \\
\cline { 2 - 3 } & Take action for improvement & $\begin{array}{l}\text { Compare institutional models with reality model. Make } \\
\text { changes systematically desired. Take corrective action }\end{array}$ \\
\hline
\end{tabular}

Note: To make the discussion more effective, we shorten the flow of the Soft System Methodology (SSM) stage into the above operational definitions according to the assumptions in the SSM stage.

\section{Results and Discussion}

\section{Model Development}

\section{Building a Conceptual Model based on "root definitions":}

The description of the model development process is as follows:

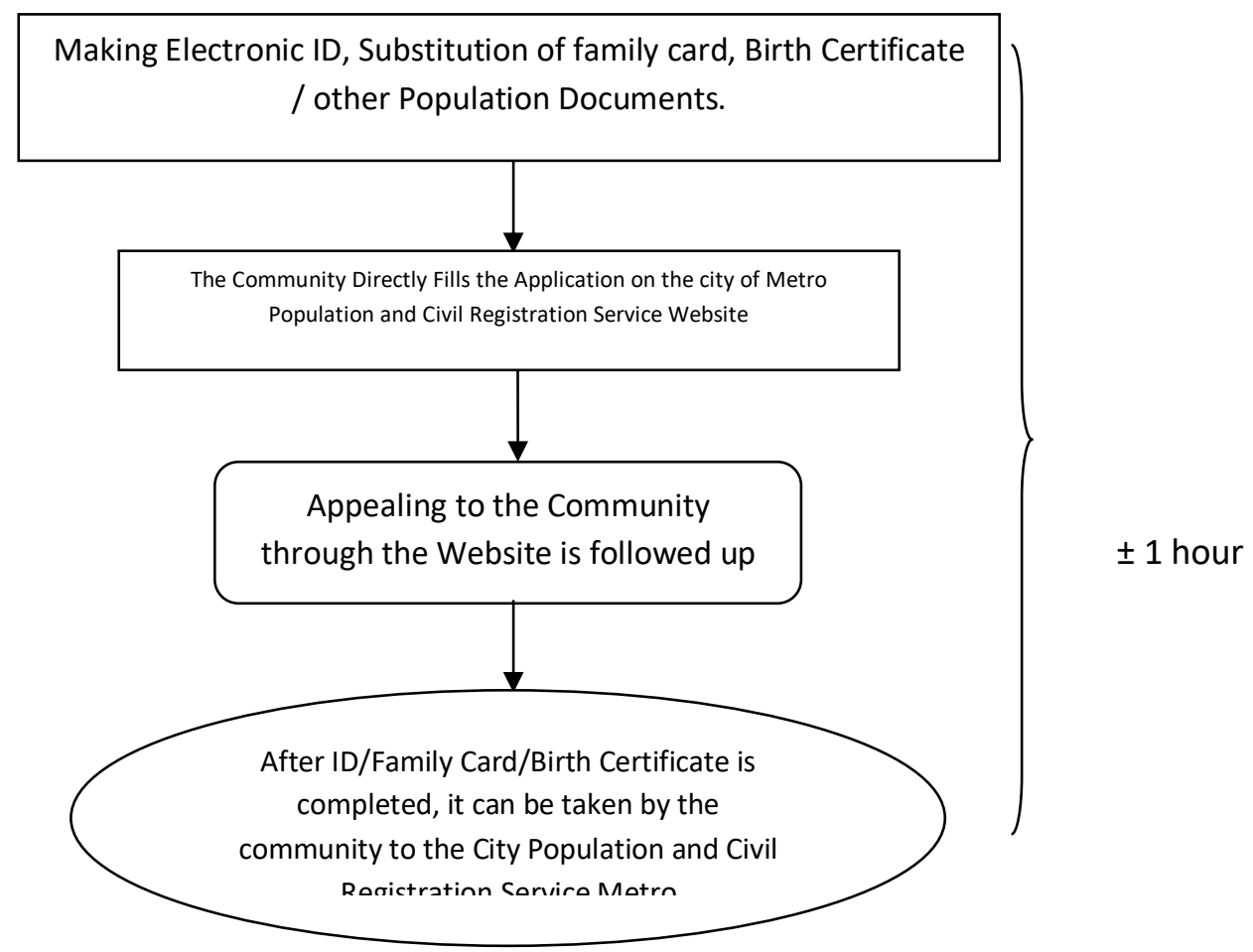

Figure 1: Model Development Process

With the development process of the following models, it is expected that population services at the Population and Civil Registration Service of city of Metro will be faster, not long and not complicated. This can be seen from the length of service time which takes 1 hour while the system of 4 (four) stages of service time reaches 4 hours, so that population administration services that are only for the Population and Civil 
Registration Service only become faster, simpler, and less complicated. It can save 3 hours. The advantages of developing this model include:

1. The applicant / citizen receiving service does not need to come to the city of Metro Population and Civil Registration Service and without having to come to the RT / RW Chairperson, Village Office and Sub-district Office to fill out and make a cover letter of making population administration (Family Card/ID/ Birth Certificate/and other documents). Applicants simply fill in the residence form (making lost ID/Family card or a Birth Certificate) through application of population on the city of Metro Population and Civil Registry Service Web site. After the residence document has been established, the Applicant/Society can immediately take it at the city of Metro Population and Civil Registration Service.

2. The long and convoluted bureaucratic path can be trimmed, so that the service becomes simple, fast, and easy. The impacts arising from the development of this model include the need for an RT / RW, Village Administrative, and Sub district cover letter in the management of population documents that do not experience changes in population data such as the making of lost ID cards or family cards and birth certificates. This of course will not reduce the duties and authority of heads of RT / RW, Village Chief, and Sub-district head as regional authorities in the area of RT / RW, Village administrative and sub district because of the administrative management of population administration documents that experience changes in population data such as Moving/Coming Letter Documents stay through the introduction of the Chairperson of RT / RW, Village administrative, and Sub-district.

\section{Take Action to Repair}

\section{Comparison between Institutional Models and Realities:}

To find out the usefulness of the improvement of the procedure system for making Electronic ID Card/Family Card/Birth Certificate and which parts need to be improved in the institutional model system a comparison between the institutional model and the reality model is needed, namely:

Table 3: Comparison between Institutional Models and Realities

\begin{tabular}{|l|l|l|}
\hline Problem & Institutional Model & Reality Model \\
\hline $\begin{array}{l}\text { Slow service and } \\
\text { convoluted }\end{array}$ & $\begin{array}{l}\text { 4 stage service system } \\
\text { making the service slow and } \\
\text { convoluted }\end{array}$ & $\begin{array}{l}\text { Service becomes long and the } \\
\text { applicant / community must come } \\
\text { from 1 place to other places }\end{array}$ \\
\hline The queue is not regular & $\begin{array}{l}\text { The community is still irregular in } \\
\text { queuing at the registration counter }\end{array}$ & $\begin{array}{l}\text { The absence of a monitor screen } \\
\text { queue and queue application }\end{array}$ \\
\hline $\begin{array}{l}\text { There are still intermediaries } \\
\text { (scalper) inside ID/Family Card } \\
\text { services }\end{array}$ & $\begin{array}{l}\text { There is still a lack of supervision } \\
\text { from related agencies employee }\end{array}$ & $\begin{array}{l}\text { Personnel still received lots of files } \\
\text { service from intermediaries in return }\end{array}$ \\
\hline
\end{tabular}

Source: Research 2018

\section{Doing Systematic and Desired Changes:}

Making systematic and desirable changes that include:

- Making the service process on the direct service system at the Population and Civil Registration Service without having to go to the Chairperson of the RT, Head of the Village Office, and the Subdistrict Office so that service to the community becomes faster and less complicated.

- The Head of the Office of Population and Civil Registration of city of Metro can procure a queue monitor screen and its application.

- Establish a joint team of service supervisors from the relevant agencies to monitor services at the city of Metro Population and Civil Registration Service, in order to eradicate brokers (intermediaries) who make ID card/Family Card/Birth Certificates. 


\section{Take Action to Improve the Problem Situation:}

In the table there are three comparisons of conceptual models (ideal) with reality in the field to find out the gaps that occur to provide recommendations for improvement. Whereas to make the desired change action based on the uptake of information obtained from observations and interviews with sources, namely from the Chairperson of the RT/RW, the Village Head, Sub-District Head and Population Office and Civil Registration of city of Metro can be considered as follows:

Table 4: Change Measures to Bridge the Gap between Institutional Model and Reality

(Reality in the Field)

\begin{tabular}{|c|c|c|c|}
\hline Problem & Institutional Model & Reality Model & Change Action \\
\hline Old and convoluted service & $\begin{array}{l}\text { The 4-stage service } \\
\text { system makes service slow } \\
\text { and convoluted }\end{array}$ & $\begin{array}{l}\text { Services are long and the } \\
\text { applicant / community must } \\
\text { come from one place to } \\
\text { another }\end{array}$ & $\begin{array}{l}\text { Making the service process } \\
\text { on a single-stage system, } \\
\text { namely the Department of } \\
\text { Population and Civil } \\
\text { Registration. } \\
\text { This will accelerate the } \\
\text { process of population } \\
\text { administration services }\end{array}$ \\
\hline Irregular queues & $\begin{array}{l}\text { The community is still } \\
\text { irregular in queuing at the } \\
\text { registration counter and } \\
\text { payment and collection }\end{array}$ & $\begin{array}{l}\text { There is no queue monitor } \\
\text { screen }\end{array}$ & $\begin{array}{l}\text { Head of the Population } \\
\text { Office and Civil registration } \\
\text { of the city of Metro can } \\
\text { procure a queue monitor } \\
\text { screen and queue } \\
\text { application. }\end{array}$ \\
\hline $\begin{array}{l}\text { There is still an } \\
\text { intermediary (broker) in the } \\
\text { manufacturing service of ID } \\
\text { card, Family card, and Birth } \\
\text { Certificate }\end{array}$ & $\begin{array}{l}\text { There is still a lack of } \\
\text { supervision from relevant } \\
\text { agencies to employees }\end{array}$ & $\begin{array}{l}\text { There are still many } \\
\text { employees who receive } \\
\text { service files from } \\
\text { intermediaries in return and } \\
\text { they still throw } \\
\text { responsibility at each other }\end{array}$ & $\begin{array}{l}\text { - Forming a joint team of } \\
\text { service supervisors from } \\
\text { the relevant agencies } \\
\text { monitors the services of the } \\
\text { Metro City Population and } \\
\text { Civil Registration Service } \\
\text { - Simplify the procedures } \\
\text { and service processes of } \\
\text { the Population and Civil } \\
\text { Registration Service } \\
\text { - Fast and precise service } \\
\text { can be realized }\end{array}$ \\
\hline
\end{tabular}

Source: Research Result, 2018

\section{Conclusions}

Based on the description and results of the research and discussion on the design of the excellent service model with a soft system method, we can draw conclusions as follows:

i. The Population Administration Service System at the city of Metro Population and Civil Registration Service that uses a four-stage system is considered to be less effective and slow because the applicant/community must come to the Chairperson of the RT/RW, Village Administrative Office, Sub-district Office and then to the City Population and Civil Registration Office of the city of Metro. This is considered convoluted and slow.

ii. The implementation of the queuing system at the service counters under the FIFO principle is considered to be an irregular queue solution in the city of Metro Population and Civil Registry Service because if the community arrives early, the management process will also be completed earlier.

iii. Brokers are still found in the services of the city of Metro Population and Civil Registration Service due to lack of supervision from the relevant agencies, it is not yet clear the application of the Procedure Service Standards, as well as the lack of socialization to the public regarding the service rates and service procedures. 
Barusman et al. / International Journal of Research in Business and Social Science,

Vol 8 No 2, 2019 ISSN: 2147-4486

iv. With the development process, the model is expected to have population service at the city of Metro Population and Civil Registration Service to be only 1 hour, while the 4 (four) stages of service time reach 4 hours, so population administration services at the Population and Civil Registration Service become faster, simpler, and not complicated so it can save 3 hours.

Based on the above conclusions, we present several implications relating to excellent service in the city of Metro Population and Civil Registration Service with the soft system method, as follows:

i. It is necessary to familiarize the public with procedures for population administration services so that the public knows about procedures for administering population administration services in the city of Metro.

ii. Good cooperation and coordination between related work units that are in the city of Metro Government are needed, so that miss communication and miss control will not happen again which will ultimately lead to excellent service in the city of Metro Population and Civil Registration Service.

iii. Strict oversight is required of employees at the city of Metro Population and Civil Registration Service and related work units, so that the employee does not receive files from intermediaries (brokers).

iv. The city of Metro Population and Civil Registry Office is testing the model of design of population administration services that are fast and precise and not complicated with population document management service models that do not experience changes in data by the way the community directly fills the application for online population documents directly connected with the city of Metro Population and Civil Registry Service without having to go through the Heads of RT / RW, Village Chief, and Sub-district head. After the documents have been published and finished, the applicant will only come to the city of Metro Population and Civil Registry Service.

\section{References}

Gouthier, M., Ganz, W., Gieze, A., and Bartl, C. 2014. Delivering Excellent Service: Evaluation of Service Excellence Models. EBS Business School, Fraunhofer IAO.

Pratomo \& Shaff, Akhsin. 2000. Pelayanan Prima. Bandung: Angkasa Bandung.

Rust, R.; Oliver, R. (2000): Should we delight the customer?, Journal of the Academyof Marketing Science, Vol. 28 No. 1, pp. 86-94.

Minister of State for Administrative Reform Number: KEP / 81 / M.PAN / 05/1993.

Lewis, R. C. and Booms, B. H. (1983). The marketing aspects of service quality. In Emerging Perspectives on Services Marketing (L. Berry, G. Shostack and G. Upah, eds), pp. 9 104. Chicago: American Marketing Association.

Oliver, R.L., Balakrishnan, P.V. S. and Barry, B., "Outcome Satisfaction in Negotiation: A Test of Expectancy Disconfirmation," Organizational Behavior and Human Decision Processes, Vol. 60, no. 2, 1994, Pages 252-27.

Mwangi, A., Kabare, N., \& Wanjau, K. (2018). Influence of Perceived Service Quality on Consumer Satisfaction amongst Dairy Milk Processors in Kenya. International Journal of Research in Business and Social Science (2147-4478), 7(4), 44-57.

Sadiartha, A. A., \& Mirah Apsari, G. A. (2019). The Role of Satisfaction in Mediating the Effect of Services Quality on the Customers' Loyalty in the Village Credit Institution of Pekraman, Tabanan. International Journal of Research in Business and Social Science (2147-4478), 8(1), 7389.

Vardarlier, P., \& Cakir, R. (2015). A Study on Sustainable Innovation Profile of Turkey. International Journal of Research in Business and Social Science (2147-4478), 4(4), 24-35.

Sutton, C. (2013). Adapting The Human Sigma Instrument to Enhance The Employee- Customer Encounter. Service Excellence in Management. CTF, Service Research Center, Karlstad University, Sweden. 
Barusman et al. / International Journal of Research in Business and Social Science, Vol 8 No 2, 2019 ISSN: 2147-4486

Gashema, B., \& Gao, Y. (2018). Strengthening Managerial Innovation Behavior in the SMEs. International Journal of Research in Business and Social Science (2147-4478), 7(3), 36-56.

Showkat, Nayeem \& Parveen, Huma. (2017). In-depth Interview. e-PG Pathshala (UGC \& MHRD)

Sugiyono.2005.Metode Penelitian Administrasi. Bandung, Alfabeta.

Barusman, Yusuf Sulfarano. 2018. Soft Systems Methodology Solusi untuk Kompleksitas Manajemen. Bandar Lampung: UBL Press. 